\title{
Incorporation of titanium dioxide nanoparticles in mortars - Influence of microstructure in the hardened state properties and photocatalytic activity
}

\author{
S.S. Lucas ${ }^{\text {a,* }}$, V.M. Ferreira ${ }^{\text {a }}$, J.L. Barroso de Aguiar ${ }^{\text {b }}$ \\ a University of Aveiro/CICECO, Department of Civil Engineering, 3810-193 Aveiro, Portugal \\ b University of Minho, Department of Civil Engineering, Campus de Azurém, 4800-058 Guimarães, Portugal
}

\section{A R T I C L E I N F O}

Article history:

Received 27 April 2012

Accepted 25 September 2012

\section{Keywords:}

Mortar (E)

Microstructure (B)

Mechanical Properties (C)

Cement (D)

\begin{abstract}
A B S T R A C T
The environmental pollution in urban areas is one of the causes for poor indoor air quality in buildings, particularly in suburban areas. The development of photocatalytic construction materials can contribute to clean the air and improve sustainability levels. Previous studies have focused mainly in cement and concrete materials, disregarding the potential application in historic buildings.

In this work, a photocatalytic additive (titanium dioxide) was added to mortars prepared with aerial lime, cement and gypsum binders. The main goal was to study the way that microstructural changes affect the photocatalytic efficiency. The photocatalytic activity was determined using a reactor developed to assess the degradation rate with a common urban pollutant, $\mathrm{NO}_{\mathrm{x}}$. The laboratory results show that all the compositions tested exhibited high photocatalytic efficiency. It was demonstrated that photocatalytic mortars can be applied in new and old buildings, because the nanoadditives do not compromise the mortar hardened state properties.
\end{abstract}

(c) 2012 Elsevier Ltd. All rights reserved.

\section{Introduction}

The photocatalytic phenomena using materials such as titanium dioxide $\left(\mathrm{TiO}_{2}\right)$ have been intensively investigated in the past 50 years, but the first studies date back to the 30s of the last century and some authors even refer published work on photocatalytic properties from 1920 [1]. The most common crystalline forms of titanium dioxide are anatase and rutile [2]. Rutile is employed as pigment in plastics, paints and paper. The anatase, for its great photocatalytic abilities, is widely used in air and water cleaning systems [3]. A third form, brookite, is more difficult to produce and its potential applications are not fully explored [4,5]. The use in photoelectrochemical cells for solar energy conversion was the first application investigated [6]. By the late 70s, when the first studies on the application of photocatalysis in water pollution were published, several organic and inorganic compounds were analysed [7]. During the following years, photocatalysis for water and air purification has been a subject of extensive research and, more recently, the applications have widened to surfaces with self-cleaning, self-sterilizing, bactericidal and anti-fog properties [3].

Titanium dioxide has a band gap energy of $3.2 \mathrm{eV}$, which corresponds to a wavelength of $385 \mathrm{~nm}$, so, electron-hole pairs are generated when titania is irradiated with light with this wavelength [8].

\footnotetext{
* Corresponding author. Tel.: + 351234370 049; fax: + 351234370094.

E-mail addresses: sandra.lucas@ua.pt (S.S. Lucas), victorf@ua.pt (V.M. Ferreira), aguiar@civil.uminho.pt (J.L.B. de Aguiar).
}

The reactions involved in the photocatalytic process are detailed in the following equations:

$$
\begin{aligned}
& \mathrm{TiO}_{2}+\mathrm{hf} \rightarrow \mathrm{TiO}_{2}+\mathrm{e}^{-}+\mathrm{h}^{+} \\
& \mathrm{e}^{-}+\mathrm{O}_{2} \rightarrow \mathrm{O}_{2}^{-} \\
& \mathrm{h}^{+}+\mathrm{H}_{2} \mathrm{O} \rightarrow \mathrm{HO}+\mathrm{H}^{+} .
\end{aligned}
$$

The electrons of the conduction band, with strong reducing potential, react with oxygen to produce superoxide radicals (2). The generated electron gaps react with the water molecules surrounding the titanium dioxide particles generating hydroxyl groups (3). These free radicals will react with the pollutant molecules converting them into other compounds. The high oxidizing and reducing abilities of $\mathrm{TiO}_{2}$ make it one of the most efficient photocatalyst. It is commonly used in degradation of organic pollutants and aromatic compounds, solar energy conversion, bacteria, viruses and cancer cell destruction, self-cleaning and anti-fog surfaces [9]. Currently, one of the most important applications of photocatalysis is the decontamination, disinfection and deodorization of indoor air $[10,11]$. The recent years of development in the nanomaterials field allowed the use of titania nanoparticles, which improved the efficiency of the photocatalytic process, as a result of the higher specific surface area [12]. There is a growing concern in the EU about indoor air quality levels, which was reflected in a set of rules intended to reduce the health effects of poor air quality $[13,14]$. This orientation gave rise to a strong investment in the research of photocatalytic technology to reduce 
pollutant levels in the air [11]. The atmosphere inside buildings can suffer contamination from internal sources (furniture, paint, appliances) or external (traffic, industry), which results in the presence of various pollutants ( $\mathrm{VOC}, \mathrm{NO}_{\mathrm{x}}, \mathrm{SO}_{\mathrm{x}}$, formaldehyde, etc.) $[15,16]$. With respect to pollutants from external sources, $\mathrm{NO}_{\mathrm{x}}$ is one of the most common in urban areas. Conventional indoor air cleaning methods are usually ineffective since they merely replace the contaminated air by new polluted air (ventilation systems) or change the pollutant to another phase without neutralizing it (air purifiers). $\mathrm{TiO}_{2}$ has a good removing efficiency of these substances, for concentrations between 0.01 and $10 \mathrm{ppmv}$, presenting itself as a good solution for indoor air cleaning $[17,18]$. The possibility to incorporate titanium dioxide nanoparticles in construction materials (cement, plaster, concrete, etc.) has been investigated in recent years leading to the development of products like TioCem, already on the market [19-21]. The photocatalytic reaction takes place on the surface of these materials where the adsorption of the gaseous pollutants occurs. Later, with the removal of the reaction products from the active sites, the catalyst becomes active again, making it capable of accomplishing a new photocatalytic process [1].

VOC (volatile organic compounds) have been used to model the photocatalytic response in the degradation of indoor air pollutants because they are a common indoor pollutant. The finishes, furnishings and equipments used in construction can release them and the reaction products are substances like $\mathrm{CO}_{2}$ and $\mathrm{H}_{2} \mathrm{O}$. However, VOC are toxic and difficult to handle due to the risks posed to human health. Tests with these gasses have been conducted to evaluate the efficiency of materials such as paints in indoor air cleaning [22]. Concerning their application with mortars, one of the reaction products, $\mathrm{CO}_{2}$, can be a problem. Carbonation occurs, in mortars with aerial binders, in the presence of $\mathrm{CO}_{2}$, therefore the use of VOC might affect the material hardened state properties, since it promotes carbonate precipitation on the surface, which could influence the final results [23,24].

Alternatively, other pollutants can be used such as $\mathrm{NO}_{\mathrm{x}}$. This gas is released into the air by traffic and industry and is responsible for acid rain in urban areas, which is one of the major causes of deterioration in old buildings located in the historic cities' centers [25]. This pollutant is presented indoor by the contamination from the exterior air that enters through ventilation systems and windows, therefore it is a suitable gas to conduct this study [26]. Several authors describe the mechanism concerning the degradation of $\mathrm{NO}_{\mathrm{x}}$ as a process consisting a series of reactions that take place in several stages and involve the production of reaction intermediates. The $\mathrm{O}^{2-}$ and $\mathrm{OH} \bullet$ radicals formed during the activation process of the photocatalyst as described in Section 1, react with the pollutant gas producing $\mathrm{NO}_{2}$ and $\mathrm{HNO}_{3}$ [27].

$$
\begin{aligned}
& \mathrm{NO}+\mathrm{OH}^{\cdot} \rightarrow \mathrm{NO}_{2}+\mathrm{H}^{+} \\
& \mathrm{NO}+\mathrm{O}_{2}^{-} \rightarrow \mathrm{NO}_{3}^{-} \\
& \mathrm{NO}_{2}+\mathrm{OH}^{\cdot} \rightarrow \mathrm{NO}_{3}^{-}+\mathrm{H}^{+} \rightarrow \mathrm{HNO}_{3}
\end{aligned}
$$

The photocatalytic efficiency is determined according to Eq. (7), where $C_{i}$ stands for the initial pollutant concentration and $C_{f}$ for the final.

$\eta(\%)=1-\frac{C_{f}}{C_{i}} \times 100$

The $\mathrm{NO}_{\mathrm{x}}$ can be used to evaluate the decontamination abilities of mortars in a concentration range between 0.01 and 10 ppmv [17,18].

This work aims to study how the microstructural changes caused by the introduction of the titanium dioxide nanoparticles affect the photocatalytic performance. Several mortars, prepared with different binders (lime, cement and gypsum) were tested and their microstructure and internal pore distribution were analyzed. The influence of some operational parameters was assessed (pollutant concentration and deactivation time) in the photocatalytic activity. Finally, the efficiency of the catalyst doped with iron was evaluated and compared with the non-doped titanium dioxide.

\section{Experimental}

\subsection{Materials and formulations}

The raw materials used for the mortar preparation consist of commercial aerial lime (Calcidrata), Portland cement CEM II 32.5 N, gypsum (SIVAL) as binders and siliceous sand as aggregate (Table 1 ). The titanium dioxide, used as a photocatalyst additive, is a commercial product (Degussa P25), consisting of $85 \%$ of anatase and $15 \%$ rutile, with a specific surface area of $50 \pm 15 \mathrm{~m}^{2} \mathrm{~g}^{-1}$. A superplasticizer (Glenium 51) was added as an admixture to all compositions (0.5 wt.\%) in order to control the workability and water content.

Mortars were prepared with those different binders and compositions, which are summarized in Table 2. For each formulation, mortars with $0,0.5,1,2.5$ and 5 wt.\% of $\mathrm{TiO}_{2}$ added to the total solid content were tested. The mortar workability was adjusted using the flow table. The amount of water added in relation to the total weight of solid material varies in order to keep constant the slump value for each composition (Table 3).

To assure the test reproducibility a methodology for the preparation of mortars was defined, and was followed throughout the study.

- Solid material weighing (raw materials and additives)

- Manual homogenization in a sealed plastic bag

- Weighing of superplasticizer and mixing water

- Addition of superplasticizer to the mixing water

- Mixing of solids with the liquid

- Homogenization in a blender for $60 \mathrm{~s}$

- Manual mixing for $60 \mathrm{~s}$ and homogenization for $90 \mathrm{~s}$, in the automatic blender.

\subsection{Mortar characterization}

In order to ensure a proper workability the adjustment of the mixing water was made according to the flow table, following the procedure described in the European Standard EN 1015-3. For the mechanical tests, specimens $(40 \times 40 \times 160 \mathrm{~mm})$ were prepared in accordance with the EN 1015-11 standard. The test was done after 90 days of curing, the only exception was the cement mortar composition (C), which was tested after 28 days. All specimens and samples were placed for curing in a chamber with controlled temperature and humidity $\left(20{ }^{\circ} \mathrm{C} \pm 2{ }^{\circ} \mathrm{C}\right.$ and $\left.65 \% \pm 5 \%\right)$ until the tests were performed. The porosity distribution and pore size analysis was performed with a mercury porosimeter (Micromeritics AutoPore IV), working with a pressure between $4 \mathrm{kPa}$ and $228 \mathrm{MPa}$ allowing mercury intrusion in pores with diameters from $5.5 \mathrm{~nm}$ to $360 \mu \mathrm{m}$, after 90 days for all the formulations.

Table 1

Average particle size of the selected raw materials.

\begin{tabular}{ll}
\hline & Average particle size \\
\hline Lime & $4 \mu \mathrm{m}$ \\
Cement & $17 \mu \mathrm{m}$ \\
Gypsum & $23 \mu \mathrm{m}$ \\
Sand & $440 \mu \mathrm{m}$ \\
$\mathrm{TiO}_{2}$ & $21 \mathrm{~nm}$ \\
\hline
\end{tabular}


Table 2

Compositions tested (references and formulations).

\begin{tabular}{|c|c|c|c|c|c|c|}
\hline \multicolumn{2}{|c|}{ Composition } & \multirow{2}{*}{$\frac{0 \% \mathrm{TiO}_{2}}{25}$} & \multirow{2}{*}{$\begin{array}{l}0.5 \% \mathrm{TiO}_{2} \\
24.9\end{array}$} & \multirow{2}{*}{$\frac{1 \% \mathrm{TiO}_{2}}{24.8}$} & \multirow{2}{*}{$\begin{array}{l}2.5 \% \mathrm{TiO}_{2} \\
24.4\end{array}$} & \multirow{2}{*}{$\begin{array}{l}5 \% \mathrm{TiO}_{2} \\
23.8\end{array}$} \\
\hline $\mathrm{L}$ & Lime & & & & & \\
\hline & Sand & 75 & 74.6 & 74.3 & 73.2 & 71.4 \\
\hline & $\mathrm{TiO}_{2}$ & 0 & 0.5 & 1 & 2.4 & 4.8 \\
\hline \multirow[t]{4}{*}{ LC } & Lime & 9 & 9 & 8.9 & 8.8 & 8.6 \\
\hline & Cement & 13 & 12.9 & 12.9 & 12.7 & 12.4 \\
\hline & Sand & 78 & 77.6 & 77.2 & 76.1 & 74.3 \\
\hline & $\mathrm{TiO}_{2}$ & 0 & 0.5 & 1 & 2.4 & 4.8 \\
\hline \multirow[t]{4}{*}{ LG } & Lime & 12 & 11.9 & 11.9 & 11.7 & 11.4 \\
\hline & Gypsum & 8 & 8 & 7.9 & 7.8 & 7.6 \\
\hline & Sand & 80 & 79.6 & 79.2 & 78 & 76.2 \\
\hline & $\mathrm{TiO}_{2}$ & 0 & 0.5 & 1 & 2.4 & 4.8 \\
\hline \multirow[t]{3}{*}{ C } & Cement & 20 & 19.9 & 19.8 & 19.5 & 19 \\
\hline & Sand & 80 & 79.6 & 79.2 & 78 & 76.2 \\
\hline & $\mathrm{TiO}_{2}$ & 0 & 0.5 & 1 & 2.4 & 4.8 \\
\hline \multirow[t]{3}{*}{ G } & Gypsum & 20 & 19.9 & 19.8 & 19.5 & 19 \\
\hline & Sand & 80 & 79.6 & 79.2 & 78 & 76.2 \\
\hline & $\mathrm{TiO}_{2}$ & 0 & 0.5 & 1 & 2.4 & 4.8 \\
\hline
\end{tabular}

\subsection{Air cleaning tests}

For the degradation tests, a mixture of $\mathrm{NO}_{\mathrm{x}}$ diluted in normalized air with an initial concentration of 1 ppmv was used. To set this value for the initial concentration of the pollutant, the usual concentration values were measured for the indoor air in several environmental studies as well as the concentration used by other authors in similar $\mathrm{NO}_{\mathrm{x}}$ degradation studies [28-30]. The main purpose was to establish a proper comparison of this work with the former studies.

Fig. 1 exhibits a schematic diagram of the instrumentation used for these tests. The inlet gas was prepared using a normalized air bottle and a $\mathrm{NO}_{\mathrm{x}}$ gas cylinder with a concentration of $10 \mathrm{ppmv}$. Two mass flow controllers were used to prepare a mixture of air with 1 ppmv of $\mathrm{NO}_{\mathrm{x}}$, with a flow rate of $1 \mathrm{l} / \mathrm{min}$. The reactor configuration was based on the requirements for the indoor air exchange rate defined by the Portuguese legislation, which considers a reference value of 0.6 renovations per hour [31]. The reactor consists of a stainless steel cylinder with $35 \mathrm{~L}$ capacity and a sealed cover with a glass window on the top to allow the entry of light from the 300-Watt solar lamp (OSRAM UltraVitalux). The light source was fixed on a support structure placed outside the reactor at a distance of about $1 \mathrm{~m}$ from the sample. The tests were performed at $20{ }^{\circ} \mathrm{C}$ (temperature inside the reactor) and a relative humidity of $40 \%$, the air humidity requested to the gas supplier. These parameters were controlled with a thermocouple placed inside the chamber and a humidity sensor placed in the inlet pipe and remained stable during the tests. An excessive temperature increase can influence the degradation rate of the pollutant, making it difficult to ensure that the efficiency is caused exclusively by the $\mathrm{TiO}_{2}$ activity and not an overheating effect [32]. The outlet concentration of the pollutant gas was measured using a chemiluminescence analyzer (AC-30 M, Environment SA). The experimental procedure begins by placing the sample inside the reactor. Afterwards, with the reactor

Table 3

Water additions and slump value for the compositions tested.

\begin{tabular}{lllllll}
\hline \multirow{2}{*}{ Composition } & \multicolumn{2}{l}{ Water $(\mathrm{wt} . \%)$} & & \\
\cline { 2 - 6 } & $0 \%$ & $0.5 \%$ & $1 \%$ & $2.5 \%$ & $5 \%$ & \multirow{2}{*}{$\begin{array}{l}\text { Flow value } \\
(\mathrm{mm})\end{array}$} \\
\cline { 2 - 6 } & $\mathrm{TiO}_{2}$ & $\mathrm{TiO}_{2}$ & $\mathrm{TiO}_{2}$ & $\mathrm{TiO}_{2}$ & $\mathrm{TiO}_{2}$ & 21 \\
\hline $\mathrm{L}$ & 16 & 17 & 20 & 21 & 24 & 140 \\
$\mathrm{LC}$ & 15 & 16 & 15 & 16 & 19 & 140 \\
$\mathrm{LG}$ & 17 & 17 & 18 & 23 & 26 & 160 \\
$\mathrm{C}$ & 13 & 13 & 14 & 15 & 16 & 140 \\
$\mathrm{G}$ & 17 & 17 & 17 & 21 & 25 & 160 \\
\hline
\end{tabular}

window shut, the inlet gas mixture starts to flow until it stabilizes in $1 \mathrm{ppmv}$. This stabilization procedure is essential to guarantee the sample saturation, assuring that during the test, the concentration measured concerns exclusively to the photocatalytic process and there is no absorption from the sample or the reactor walls [33]. With the reactor window uncovered, the lamp is turned on until the pollutant concentration reaches the minimum level. By this moment, it is considered that the photocatalytic reaction was completed and the sample can no longer continue to decompose $\mathrm{NO}_{\mathrm{x}}$. The photocatalytic efficiency is determined based on the $\mathrm{NO}_{\mathrm{x}}$ concentration measured during the sample irradiation tests. Blank tests, using the reference samples with $0 \%$ of titanium dioxide added, were carried according to the previously described procedure. The photocatalytic activity is determined by the Eq. (8) [34]:

$\mathrm{NO}_{\mathrm{X} \text { removed }}=\frac{\left[\mathrm{NO}_{\mathrm{X}}\right]_{\mathrm{TiO}_{2}}-\left[\mathrm{NO}_{\mathrm{X}}\right]_{\text {blank }}}{\left[\mathrm{NO}_{\mathrm{X}}\right]_{\mathrm{TiO}_{2}}} \times 100$

where

$\left[\mathrm{NO}_{\mathrm{x}}\right]_{\mathrm{TiO} 2}$ is the final pollutant concentration after the irradiation test $\left[\mathrm{NO}_{\mathrm{x}}\right]_{\text {blank }}$ is the $\mathrm{NO}_{\mathrm{x}}$ concentration for the blank test.

\subsection{Influence of operational conditions in the photocatalytic process}

Some operational aspects, such as the deactivation time and initial pollutant concentration can influence the degradation efficiency. It is important to verify if the sample confinement in a place with the absence of light for a period of several hours is enough to assure the complete deactivation of the catalyzer, allowing the mortar to perform a new photocatalytic cycle when exposed to the sunlight again. This is a fundamental evaluation to determine if the mortar maintains its efficiency when subjected to several activation and deactivation series throughout its life cycle. For this purpose, a 2 cycle test was performed, with an 8 hour deactivation interval in a dark box.

To assess the influence of the pollutant concentration on the photocatalytic degradation rate a mortar sample, selected from the compositions previously tested, was submitted to cycles with concentrations of 0.5 ppmv and 0.75 ppmv. The composition was selected based on the hardened state performance and the photocatalytic degradation efficiency. Considering these results and taking into account that the mortars with lime, less studied, are particularly interesting for application in the rehabilitation of old buildings, the lime-gypsum composition (LG) was selected.

Several authors have tested different doping methods trying to increase the efficiency of the catalyst $[35,36]$. These methods involve doping titanium dioxide with metals (e.g., silver or iron). In this work a co-precipitation method was used for doping the titanium dioxide with iron $\left(\mathrm{Fe}^{+}\right)$, according to the following methodology:

- Preparation of a suspension of $\mathrm{TiO}_{2}(1 \mathrm{~g})$ in $100 \mathrm{ml}$ of water (solution 1)

- Preparation of an aqueous solution (100 ml) containing $0.01 \mathrm{~mol}$ of $\mathrm{FeCl}_{3}$ (solution 2)

- Addition of solution 2 to solution 1

- Keeping the mixture under stirring at $70{ }^{\circ} \mathrm{C}$ during $150 \mathrm{~min}$

- Filtration of the suspension and washing with distilled water

- Drying in an oven at $60{ }^{\circ} \mathrm{C}$ of the solid material obtained on filtering.

A mortar sample was prepared with 1 wt.\% nano- $\mathrm{TiO}_{2}$ doped with iron for tests in the photocatalytic reactor. This sample was compared with the same mortar composition prepared with the non-doped $\mathrm{TiO}_{2}$. 


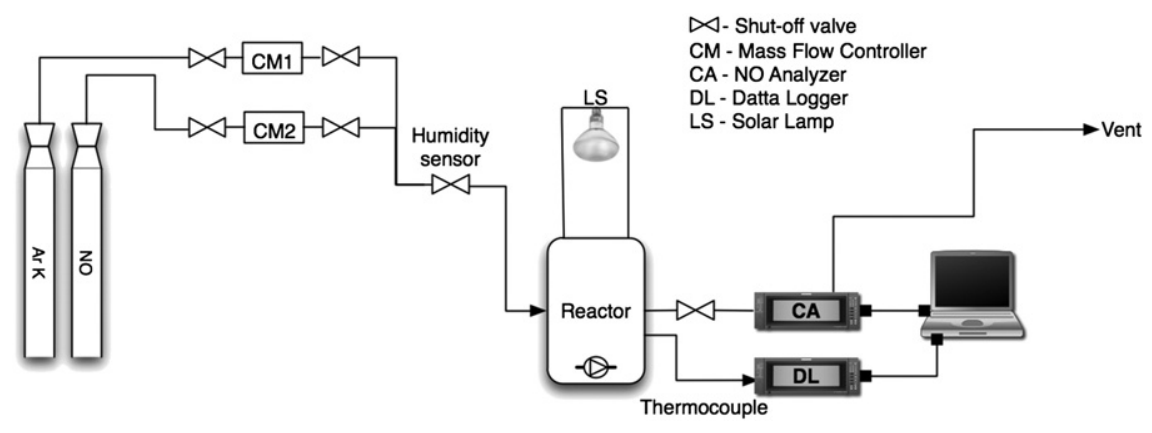

Fig. 1. Reactor for the $\mathrm{NO}_{\mathrm{x}}$ degradation tests.

\section{Results and discussion}

\subsection{Effect on mortar properties}

The incorporation of titanium dioxide nanoparticles in lime mortars (L) causes a decrease in both flexural and compression strength (Fig. 2), though this reduction is not linear with the rise of additive content. The incorporation of $0.5 \mathrm{wt} . \%$ of $\mathrm{TiO}_{2}$ reduces the flexural and compression strength. Increasing amounts up to $2.5 \mathrm{wt} . \%$ does not cause significant modifications in the flexural strength or the compressive strength. A quantity greater than $2.5 \mathrm{wt} . \%$ affects the mechanical properties however the $5 \mathrm{wt} . \%$ results are close to the 0.5 wt.\% values. It is worth mentioning that the mechanical strength remains higher than $1 \mathrm{MPa}$ up to $2.5 \mathrm{wt} . \% \mathrm{TiO}_{2}$, and only when the additive exceeds this amount the strength falls below this limit. The pore size analysis shows a bimodal distribution for all compositions, as shown in Fig. 3. This separation in two distinct pore size classes is accentuated by the introduction of $\mathrm{TiO}_{2}$ in the mortar.

It was established, in this work, that pores above $10 \mu \mathrm{m}$ are designated as macropores, and pores between 10 and $1 \mu \mathrm{m}$ are considered as micropores and below $1 \mu \mathrm{m}$ nanopores.

The reference composition ( $0 \mathrm{wt} . \%)$ exhibits a porosity distributed mostly between 0.1 and $1 \mu \mathrm{m}$, with a small amount of pores in the range of 5 to $100 \mu \mathrm{m}$. With the introduction of $0.5 \mathrm{wt} . \% \mathrm{TiO}_{2}$ the presence of macropores in the internal structure of the mortar causes a decrease in the flexural strength. The effect of an increased macroporosity $(>10 \mu \mathrm{m})$ reflects in the evolution of the mechanical properties. Titanium dioxide additions of 1 to $2.5 \mathrm{wt}$ \% cause a slight reduction in both macropores and micropores which explains the flexural strength recovery. The increase of larger pores accounts for the higher fragility of the mortar structure, for $5 \mathrm{wt} . \% \mathrm{TiO}_{2}$, regardless of a strong presence of nanopores.

Fig. 4 presents the results of the mechanical strength for a blended composition of aerial lime and cement (LC) with different amounts of

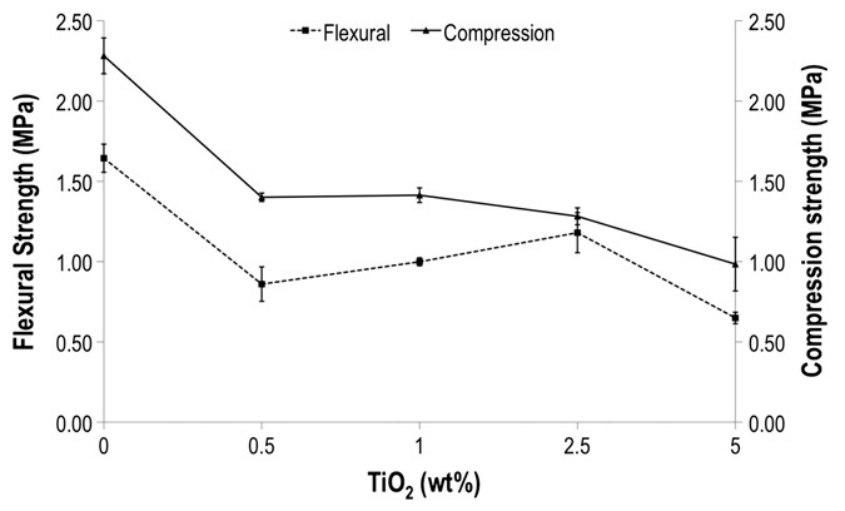

Fig. 2. Mechanical strength of the aerial lime composition (L).
$\mathrm{TiO}_{2}$ nanoparticles. The partial substitution for cement binder contributes to a higher mechanical strength in this composition (LC) compared to a lime-based mortar (L). The cement-lime mortar shows a progressive reduction of the mechanical strength with the incorporation of $\mathrm{TiO}_{2}$ nanoparticles, more pronounced above $2.5 \mathrm{wt} . \%$. The reference composition ( $0 \mathrm{wt} . \%$ ) exhibits an internal porosity distributed in two major intervals corresponding to the highest peaks in Fig. 5, 2-3 $\mu \mathrm{m}$ and $0.05-1 \mu \mathrm{m}$ (micropores and nanopores respectively), and there is also a residual amount of macropores in the range of 9 to $15 \mu \mathrm{m}$. The addition of $0.5 \mathrm{wt} . \% \mathrm{TiO}_{2}$ causes an approximation of the higher peaks, to a range between 0.06 and $1 \mu \mathrm{m}$. Although the total amount of pores increases, the residual macroporosity disappears. Establishing a comparison between the lime-based and the cement-lime mortar it can be concluded that the partial substitution with cement reduces the average pore size and the macroporosity above $1 \mu \mathrm{m}$. This effect explains the better hardened state performance of the LC mortar. The microstructure of cement-lime mortars is more complex because of the evolution of the carbonation process. The pore size distribution tends to evolve to lower size ranges (micro and nanopores). Karatasios et al. reported that the incorporation of $\mathrm{TiO}_{2}$ nanoparticles might accelerate the carbonation process which can contribute to the increase of micropores, in formulations with $\mathrm{TiO}_{2}$ additions above $1 \mathrm{wt}$ \% [24]. On the other hand, the water content rise with the increasing amount of nanoparticles contributes to a higher porosity so there is a joint effect of pore size reduction and increased porosity for the compositions with higher amounts of $\mathrm{TiO}_{2}[23,37]$.

The third mortar composition tested (LG) was a lime-gypsum plaster, commonly used in old buildings before the development of Portland cement and the consequent widespread of cement-based mortars [38]. This composition shows a reduction in the mechanical strength for $0.5 \mathrm{wt} . \% \mathrm{TiO}_{2}$ (Fig. 6 ) and recuperation when $1 \mathrm{wt} . \%$ of additive is added. This performance is common to the blended cement pastes (LC and LG) and the lime mortars, indicating that the

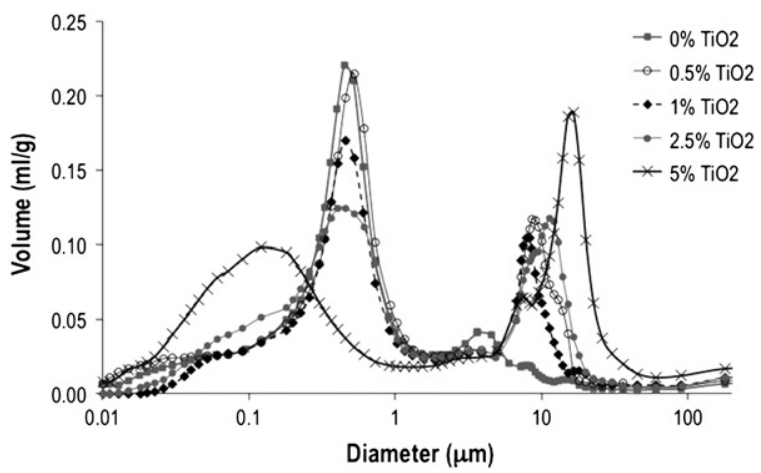

Fig. 3. Pore size distribution (a) and total porosity (b) of the aerial lime composition (L). 


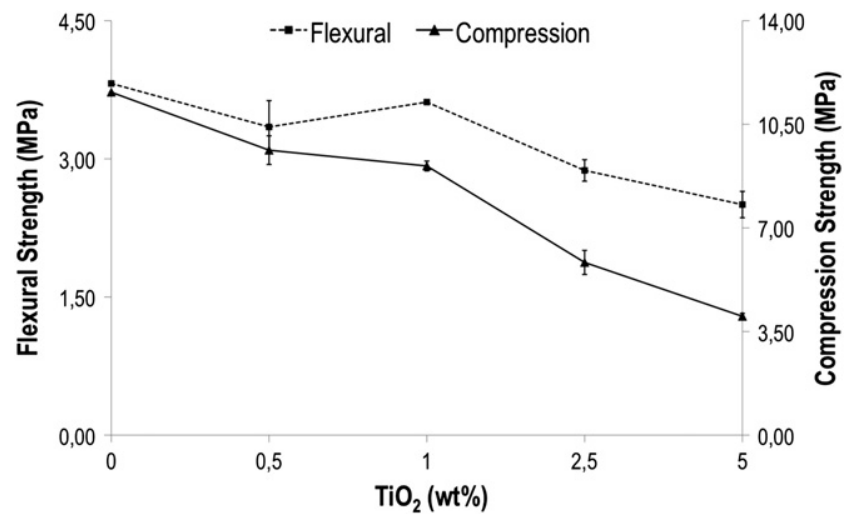

Fig. 4. Mechanical strength of the blended lime and cement composition (LC).

presence of the lime binder can favor the accommodation of up to 1 wt.\% nanoparticles and stabilizes the mechanical properties. The titanium dioxide incorporation above $2.5 \mathrm{wt}$.\% leads to a strength decrease, resulting from the higher nanoparticle content. The additive excessive content overcomes the benefit from the aerial lime binder incorporation, nevertheless, the mechanical strength remains above $1 \mathrm{MPa}$. For the LG composition, the pore size distribution exhibits similar curves for the different amounts of titanium dioxide (Fig. 7). This single mode pore size distribution differs only in the porosity range for the additive content. For the reference mortar (without $\mathrm{TiO}_{2}$ ) the pores are distributed in the interval between 1 and $3 \mu \mathrm{m}$, the increase of up to $1 \mathrm{wt} . \%$ additive reduces the pore size to an interval between 0.2 and $1.5 \mu \mathrm{m}$. The porosity distribution from $0 \mathrm{wt} . \%$ to $1 \mathrm{wt} . \% \mathrm{TiO}_{2}$ follows a very similar pattern. The variation observed in the mechanical properties results mainly from the difference in pore size and quantity. When the amount of $\mathrm{TiO}_{2}$ in the mortar varies between 2.5 wt.\% and 5 wt.\% the tendency is inverted, and the pore size increases causing a decay in the mechanical strength.

The cement based mortar $(C)$ shows a mechanical strength reduction with the increasing in additive content (Fig. 8), however, even for the maximum content $\left(5 \mathrm{wt} . \% \mathrm{TiO}_{2}\right)$, the reduction is lower than that observed in previous compositions, and remains above $15 \mathrm{MPa}$. Some authors report a mechanical strength increase with the partial substitution of cement binder for up to $1 \mathrm{wt} . \% \mathrm{TiO}_{2}$ [39], though this percentage corresponds to less than $0.3 \mathrm{wt} . \%$ on the total weight, which might be insufficient to ensure photocatalytic activity. Hassan et al. indicate that for a partial replacement of cement binder with $5 \mathrm{wt} . \%$ titanium dioxide the degradation rate reaches a maximum of $25 \%$ [40], however the authors do not mention the results for the mechanical strength. In the present study, the titanium dioxide content was

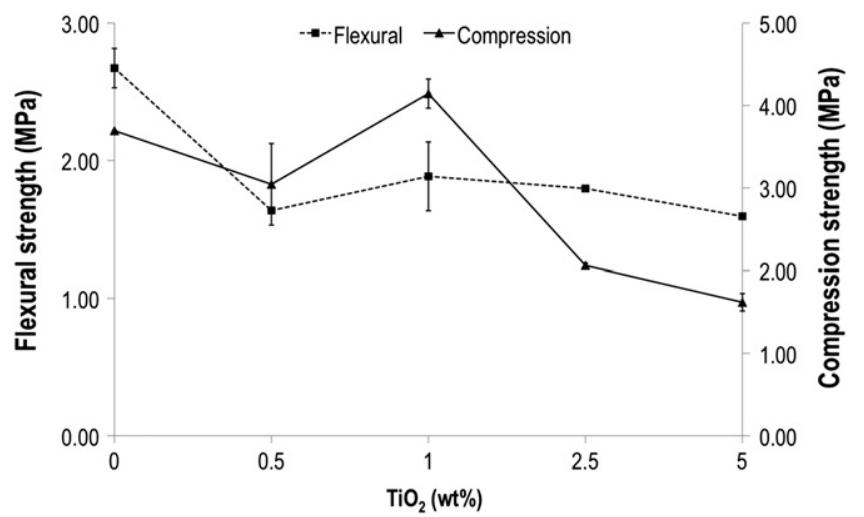

Fig. 6. Mechanical strength of the blended lime and gypsum composition (LG).

determined considering the total mass instead of a partial substitution of the binder; as a result it was used as a higher additive content and consequently a better photocatalytic performance was achieved. The porosity distribution in Fig. 9 shows the difference between the mortar without and with $\mathrm{TiO}_{2}$. In the reference or base composition, the porosity distribution is divided in two intervals; a set of pores of larger size which ranged between 10 and $60 \mu \mathrm{m}$ and another group between 0.02 and $1 \mu \mathrm{m}$. With 0.5-1 wt.\% titania added to the cement matrix, the larger pores completely disappear remaining solely pores between 0.02 and $1 \mu \mathrm{m}$; the total porosity is reduced and the compressive strength increases [39]. With $2.5 \mathrm{wt} . \% \mathrm{TiO}_{2}$, a set of nanopores begins to emerge that, combined with the disappearance of the macropores, clarify why the mechanical strength does not decrease so significantly for the cement paste as for the lime-cement composition. For the maximum $\mathrm{TiO}_{2}$ content, the nanoporosity increases notably and even with the presence of residual micropores (1.5 to $2.7 \mu \mathrm{m}$ ), the mechanical strength remains stable.

The gypsum mortar $(G)$ is the one that registers the lowest mechanical strength, where only $0.5 \mathrm{wt} . \% \mathrm{TiO}_{2}$ addition results in a $60 \%$ decrease (Fig. 10). Fig. 11 shows the pore distribution for the 0, 2.5 and $5 \mathrm{wt} . \% \mathrm{TiO}_{2}$ gypsum based compositions. In the absence of nanoparticles, the pores are distributed in two ranges: $10-45 \mu \mathrm{m}$ and $1-10 \mu \mathrm{m}$. The incorporation of $2.5-5 \mathrm{wt} . \% \mathrm{TiO}_{2}$ put in evidence the presence of pores below $10 \mu \mathrm{m}$, a significant size reduction, however not sufficient to prevent the mechanical strength decrease. Cement and blended lime-cement mortars ( $\mathrm{C}$ and LC compositions), that combine the effect of diminishing content of macropores $(>10 \mu \mathrm{m})$ with the increasing amount of nanopores $(<1 \mu \mathrm{m})$, are able to maintain a higher mechanical strength. On the contrary, gypsum mortars that exhibit only macro and micropores, above $1 \mu \mathrm{m}$, show a significant decrease.

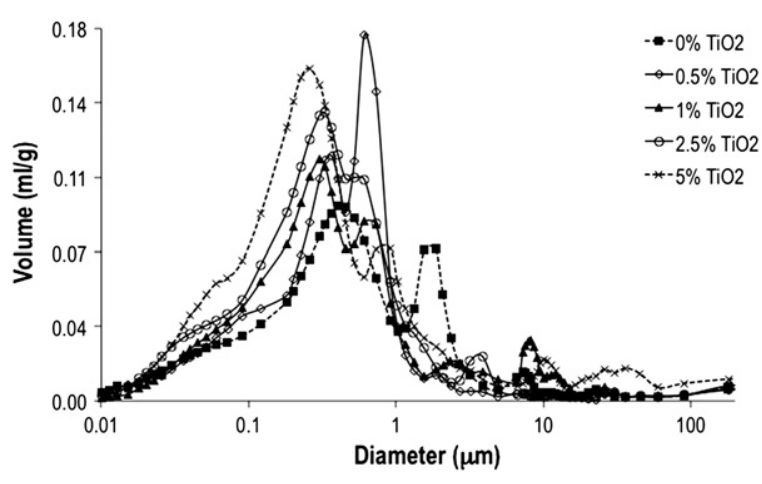

Fig. 5. Pore size distribution (a) and total porosity (b) of the blended lime and cement composition (LC).

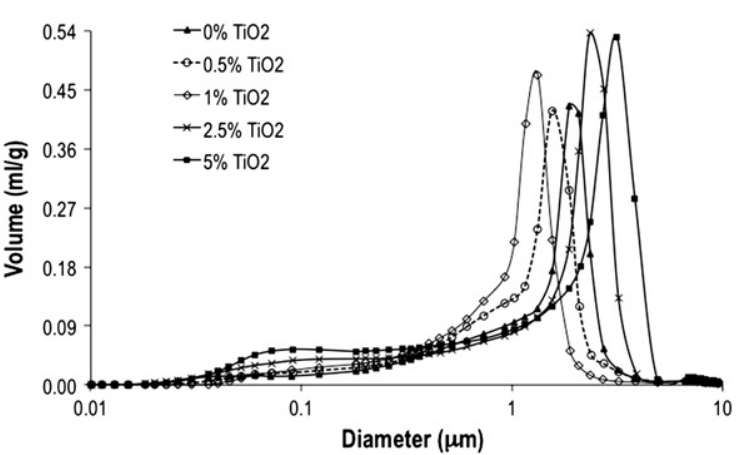

Fig. 7. Pore size distribution (a) and total porosity (b) of the blended lime and gypsum composition (LG). 


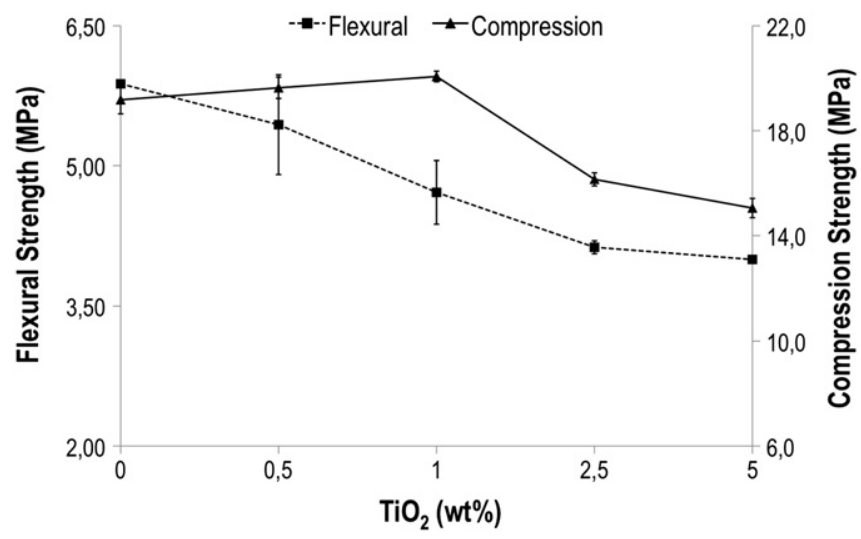

Fig. 8. Mechanical strength of the cement composition (C).

\subsection{Photocatalytic efficiency}

The $\mathrm{NO}_{\mathrm{x}}$ reduction was evaluated for all the mortar formulations according to the procedure previously described. The lime mortar (L) exhibits high photocatalytic efficiency even for the minimum additive content ( 0.5 wt.\%), as shown in Fig. 12 . The microstructural modifications observed for the different titanium dioxide contents, discussed in the prior section do not seem to determine the photocatalytic efficiency. Because the pollutant is in the gaseous state, it can reach even the micropores close to the surface. Hence, the amount of catalyst exposed will be a more important factor to determine the degradation efficiency. The decrease of the degradation rate for the samples with 2.5 and $5 \mathrm{wt} . \%$ can be related to the excess of catalyst exposed meaning that a higher porosity does not necessarily imply a higher photoactivity. The photocatalytic tests were repeated three times to confirm the consistency of these results. Carp et al. [41] mention that an excessive amount of titanium dioxide can lead to a reduction in the active sites leading to a partial deactivation. This is produced by the effect of electron-hole recombination. The absorption of a photon of energy larger than the bandgap energy leads to the formation of an electron-hole pair. This phenomenon lasts only a few nanoseconds, then the energy is dissipated and the recombination occurs. The photocatalytic activity improves with the increasing catalyst load although there is an optimum content. Excessive $\mathrm{TiO}_{2}$, among other factors, can induce faster electron-hole recombination [42].

For the lime-cement mortar (LC), the sample with only $0.5 \mathrm{wt} . \%$ of $\mathrm{TiO}_{2}$, the highest pore size range (1-0.5 $\mu \mathrm{m}$ ) has the maximum degradation rate (Fig. 13). For 1-5 wt.\% titanium dioxide the $\mathrm{NO}_{\mathrm{x}}$ degradation rate progressively decreases, even with an increasing additive

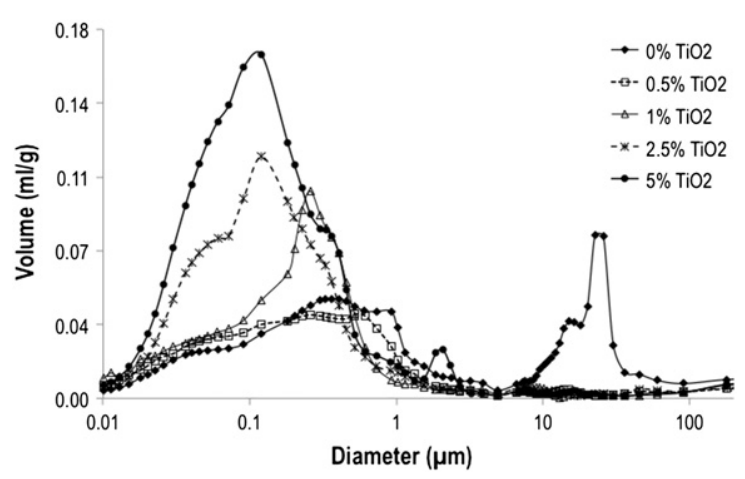

Fig. 9. Pore size distribution (a) and total porosity (b) of the cement composition (C).

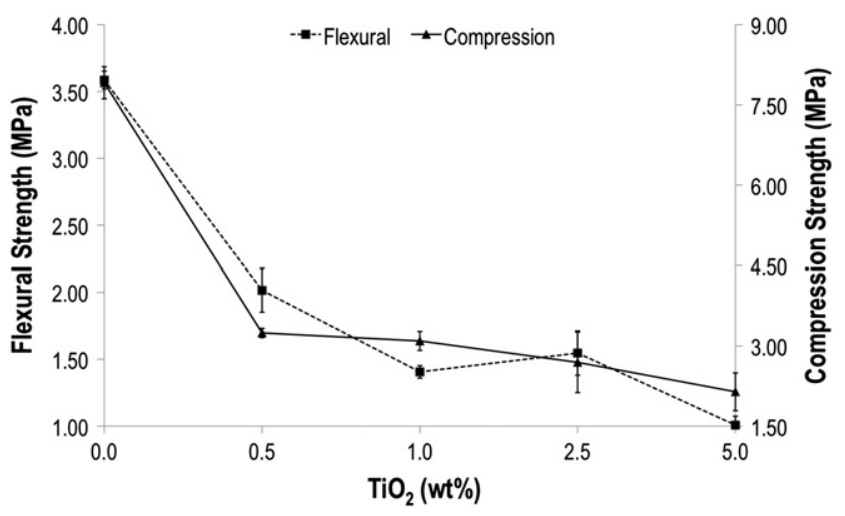

Fig. 10. Mechanical strength of the gypsum composition (G).

content and higher porosity. This behavior can result from one of the following factors:

- Prevalence of pores below $1 \mu \mathrm{m}$ (nanopores) which restrains the gas diffusion into the mortar matrix, reducing the $\mathrm{TiO}_{2}$ available for the reaction [43].

- Elevated porosity (Table 4) might cause an excessive exposure of titanium dioxide at the surface. Once the optimum content is surpassed higher electron-hole recombination can occur, leading to a partial deactivation of active sites [44].

The results demonstrate that for this particular formulation (LC) there is no benefit resulting from adding more than $0.5 \mathrm{wt} . \% \mathrm{TiO}_{2}$.

The lime and gypsum mortar (LG) exhibits higher degradation rates than the L and LC mortars (lime and blended lime-cement compositions), as seen in Fig. 14. The effect of higher pores sizes and higher porosity (Table 4) promotes the contact between the catalyst and the pollutant gas at the surface. The titanium dioxide exposure increases and consequently, the photocatalytic efficiency improves. Adding more than $1 \%$ titanium dioxide represents a $9 \%$ increase in the $\mathrm{NO}_{\mathrm{x}}$ degradation rate (from $70 \%$ to $79 \%$ ), which is not advantageous enough to counterbalance the $50 \%$ loss for the compression strength.

The overall degradation rate for the cement mortar $(C)$ is the highest among all the compositions tested, reaching approximately $80 \%$ with only 1 wt.\% $\mathrm{TiO}_{2}$ (Fig. 15). From 0.5 to 2.5 wt.\% $\mathrm{TiO}_{2}$ a higher total porosity increases the $\mathrm{NO}_{\mathrm{x}}$ degradation rate. Folli et al. [45] in a study conducted with photocatalytic cements reported that the use of titanium dioxide nanoparticles favors the degradation of gaseous pollutants even for the small size internal pores, since there is a higher pore surface area and consequently more $\mathrm{TiO}_{2}$ exposed. However, in the present study the $5 \mathrm{wt} . \% \mathrm{TiO}_{2}$ composition has the maximum

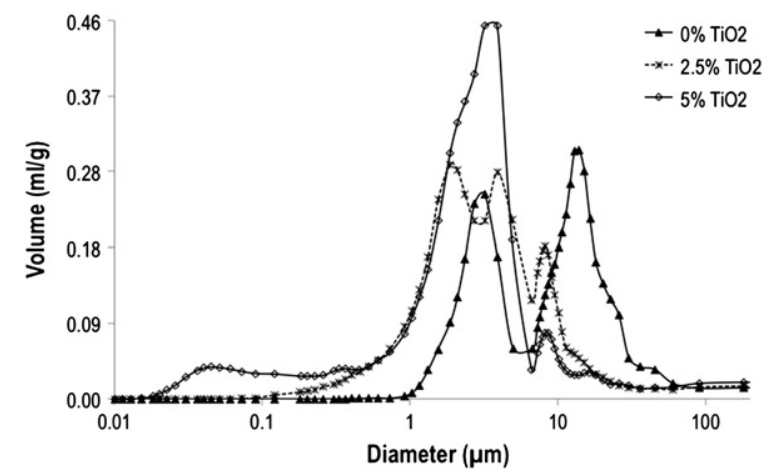

Fig. 11. Pore size distribution (a) and total porosity (b) of the gypsum composition (G). 


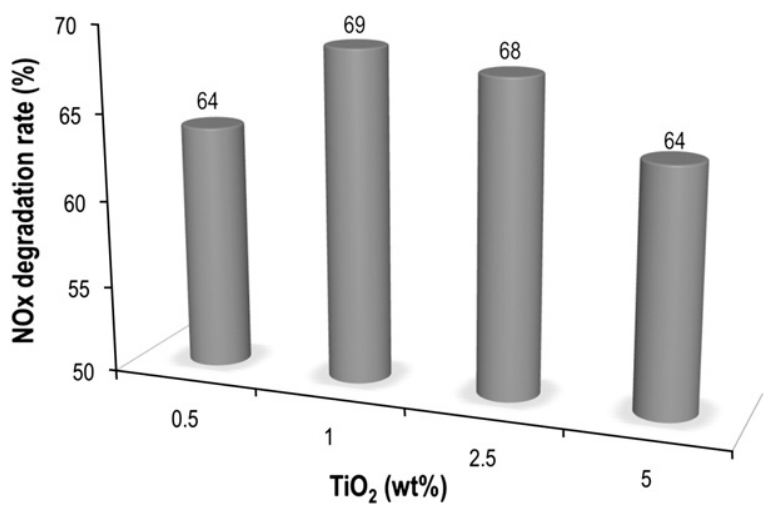

Fig. 12. $\mathrm{NO}_{\mathrm{x}}$ degradation rate of the aerial lime composition (L).

total porosity and exhibits a slight reduction of the photocatalytic activity. In this mixture, the porosity increase results from a higher amount of nanopores (below $1 \mu \mathrm{m}$ ). It can be concluded that the photocatalytic activity is favored by a higher porosity if not accompanied by a strong prevalence of nanopores, which appears to pose an obstacle for the pollutant diffusion into the cementitious matrix [43].

As seen in Fig. 16, the mortar with gypsum $(G)$ shows an increasing degradation rate. The most important increase occurs from 0.5 to $1 \mathrm{wt} . \% \mathrm{TiO}_{2}$, for higher amounts, the difference is less significant. Despite the reduction in the pore size (from approximately $20 \mu \mathrm{m}$ to $5 \mu \mathrm{m}$ ), porosity is high (above 34\%) helping internal gas diffusion and increasing the catalyst surface area.

\subsection{Influence of operational parameters in the photocatalytic activity}

The deposition of reaction products on the surface of the mortar can contribute to the temporary deactivation of some of the active sites of the catalyst. Deactivation is a critical matter when considered as functional applications for photocatalysts. Depending on the nature of the organic compound, either reversible or irreversible deactivation can occur. Deactivation is an important issue for practical applications of photocatalysts. During the degradation process, $\mathrm{TiO}_{2}$ may be deactivated due to intermediate deposition that has higher adsorption capability to the $\mathrm{TiO}_{2}$ surface than the pollutant [46]. Cao et al. [47] proved that this effect might be reversible and the catalytic activity can be completely restored.

The mortars developed in this study, when applied in buildings as an inner coating, are submitted (during the night) to an 8 hour period without sunlight. It was crucial to test if this time interval will be long
Table 4

Total porosity for the compositions tested.

\begin{tabular}{llllll}
\hline \multirow{2}{*}{ Composition } & \multicolumn{5}{l}{ Total porosity (\%) } \\
\cline { 2 - 6 } & $0 \% \mathrm{TiO}_{2}$ & $0.5 \% \mathrm{TiO}_{2}$ & $1 \% \mathrm{TiO}_{2}$ & $2.5 \% \mathrm{TiO}_{2}$ & $5 \% \mathrm{TiO}_{2}$ \\
\hline $\mathrm{L}$ & 27 & 31 & 27 & 30 & 34 \\
$\mathrm{LC}$ & 23 & 24 & 24 & 27 & 30 \\
$\mathrm{LG}$ & 30 & 29 & 29 & 33 & 37 \\
$\mathrm{C}$ & 21 & 15 & 19 & 24 & 31 \\
$\mathrm{G}$ & 34 & n. d. & n. d & 36 & 42 \\
\hline
\end{tabular}

n. d. - not determined.

enough to ensure a complete quenching of the catalyst. To evaluate the inactivation of the samples they were submitted to an initial degradation test and immediately after the test, stored in a dark box for $8 \mathrm{~h}$. After this phase, the samples were subject to another photocatalytic process to determine the degradation rate after the inactivation. The results for both photocatalytic tests, in Fig. 17, confirm the complete quenching of the mortar samples. It was demonstrated that after a period without access to light the mortar catalyst returns to the initial stage and the reaction products are removed from the surface, releasing all the active sites for a new degradation process.

In order to evaluate the photocatalytic efficiency for concentrations below 1 ppmv the samples were analyzed using pollutant concentrations of 0.7 and 0.5 ppmv (Fig. 18). A 9\% efficiency increase is observed when the pollutant concentration is reduced to $0.7 \mathrm{ppmv}$; with 0.5 ppmv the improvement is smaller (only $3 \%$ ). It can be concluded that for pollutant concentrations below 1 ppmv the $\mathrm{NO}_{\mathrm{x}}$ degradation rate increases, however this photocatalytic efficiency enhancement is not directly proportional to the pollutant concentration, meaning that it will never reach $100 \%$. The loss of photocatalytic efficiency with higher initial concentrations of pollutant can be explained by the reaction mechanism. The photocatalysis developed in two stages; initially, the electron-hole pairs are created and then the reaction with the pollutant occurs [48]. For lower concentrations, the efficiency is higher because not all active sites are used in the $\mathrm{NO}_{\mathrm{x}}$ degradation process. For higher concentrations, there is an extensive occupation of active sites in the initial phase, which slows down the subsequent reaction steps. This is caused by the formation of the intermediate products, since the $\mathrm{NO}_{\mathrm{x}}$ degradation is a two-step reaction process. A higher concentration of pollutant leads to a higher concentration of intermediate reaction products which reduces the degradation rate, causing an efficiency decrease [30,41].

To evaluate the effect of iron-doped titanium dioxide on the photocatalytic efficiency, a mortar sample with 1 wt.\% of doped $\mathrm{TiO}_{2}$ was tested in the reactor. Fig. 19 shows the results obtained for the $\mathrm{NO}_{\mathrm{x}}$

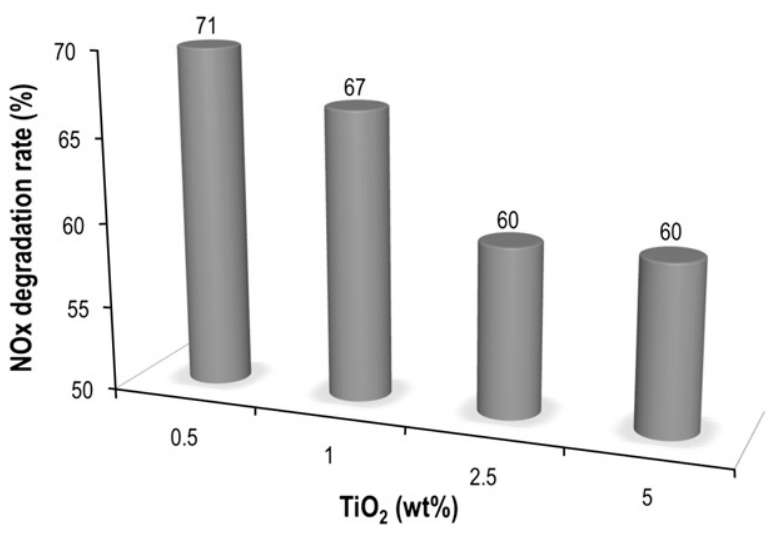

Fig. 13. $\mathrm{NO}_{\mathrm{x}}$ degradation rate of the blended lime and cement composition (LC).

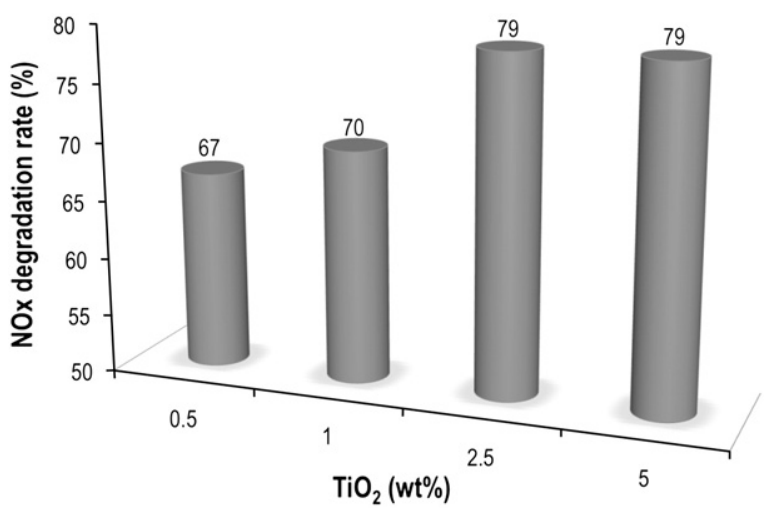

Fig. 14. $\mathrm{NO}_{\mathrm{x}}$ degradation rate of the blended lime and gypsum composition (LG). 


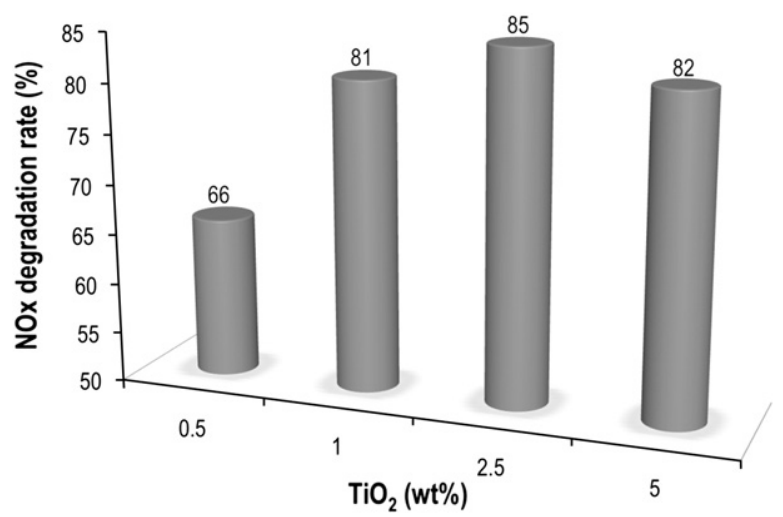

Fig. 15. $\mathrm{NO}_{\mathrm{x}}$ degradation rate of the cement composition (C).

degradation test of the mortar containing titanium dioxide doped with iron and the same composition with non-doped $\mathrm{TiO}_{2}$. The nano- $\mathrm{TiO}_{2}$ doping with iron helps to increase $6 \%$ of the $\mathrm{NO}_{\mathrm{x}}$ degradation rate, proving that it is possible to raise the photocatalytic activity of common catalysts using specific doping methods.

\section{Conclusions}

The photocatalytic additive used in this study is a nanomaterial consisting of titanium dioxide, with two crystalline phases, anatase (86\%) and rutile (14\%). This additive has a high surface area, which increases the mixing water content in order to maintain the mortar workability.

The cement and lime-cement mortars ( $\mathrm{C}$ and LC) exhibit mechanical strength loss for additions of more than $1 \mathrm{wt} . \% \mathrm{TiO}_{2}$, due to the porosity increase. For the lime-gypsum mortar (LG), the mechanical strength reduction (to an additive content above $1 \mathrm{wt} . \%$ ) is accompanied by total porosity and pore size increase. The gypsum mortar (G) is the one with the greatest mechanical strength reduction, which indicates a higher difficulty for the incorporation of the nanoparticles. In general, the presence of low size pores, particularly in the range between 1 and $0.1 \mu \mathrm{m}$ helps to minimize the detrimental effect of the introduction of nanoadditives.

Comparing the $\mathrm{NO}_{\mathrm{x}}$ degradation rates, all the compositions exhibit high photocatalytic activity even in lower additions (0.5 and $1 \mathrm{wt} . \%$ ). Considering the loss in mechanical strength, the slight increase in the degradation rate for higher amounts of additive (2.5 and $5 \mathrm{wt} . \%)$, is not enough to consider this incorporation content advantageous. The lime and lime-cement compositions (L, LC) have the highest

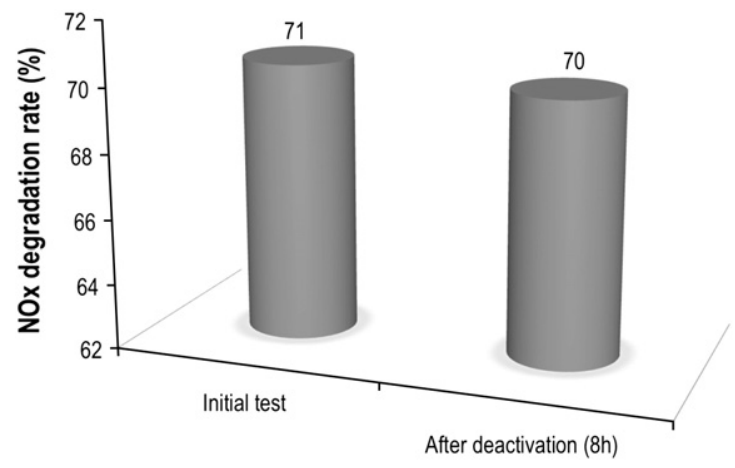

Fig. 17. Photocatalytic efficiency for the initial test and after $8 \mathrm{~h}$ of deactivation.

degradation of $\mathrm{NO}_{\mathrm{x}}$ to $0.5 \mathrm{wt} . \%$ and $1 \mathrm{wt} . \% \mathrm{TiO}_{2}$ respectively and increasing the additive content reduces the degradation rate. The remaining compositions ( $\mathrm{LG}, \mathrm{C}, \mathrm{G}$ ) show better photocatalytic activity with higher nanoparticle content.

The photocatalytic activity study of the mortars tested in this work, confirms that:

- The decrease in photocatalytic activity can result from an excessive concentration of catalyst on the mortar surface. The excess of catalyst causes a partial electron-hole pair deactivation, which can reduce the efficiency for some compositions.

- It was found that the pollutant gas could infiltrate the mortar microstructure even when the compositions present a low average pore size, which indicates that low porosity together with a strong presence of micropores $(>1 \mu \mathrm{m})$ is not an obstacle for the degradation process.

- However, it was also verified that mortars with a strong presence of nanopores $(<0.1 \mu \mathrm{m})$ exhibit an efficiency decrease. This restricted the gas intrusion in these samples, reducing the amount of catalyst exposed.

The influence that some operational factors play in the photocatalytic activity:

- When the sample is placed in a site without access to sunlight for $8 \mathrm{~h}$, the catalyst deactivates maintaining the photocatalytic efficiency in the subsequent cycles. The reaction products, absorbed at the surface during the photocatalysis, are completely removed. The deactivation test indicates that when the mortar is used in building walls, it maintain its photocatalytic efficiency.

- The reduction of the pollutant initial concentration increases the degradation rate. A lower $\mathrm{NO}_{\mathrm{x}}$ concentration reduces the number of catalyst active sites needed to degrade the pollutant, increasing

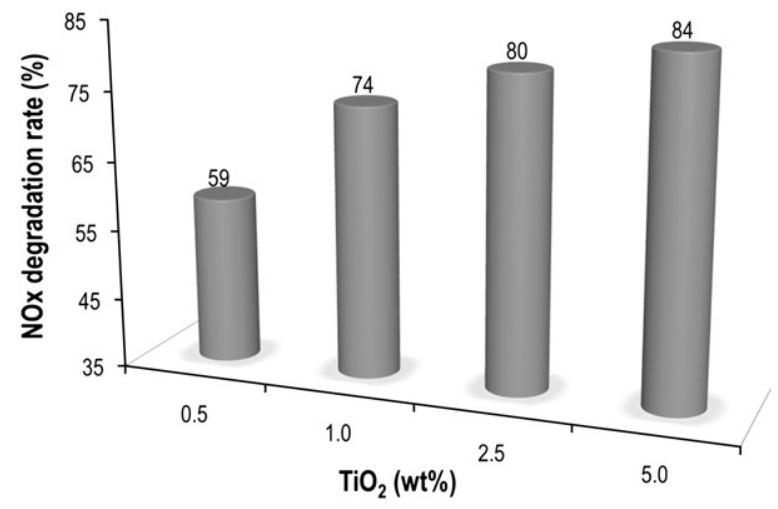

Fig. 16. $\mathrm{NO}_{\mathrm{x}}$ degradation rate of the gypsum composition (G).

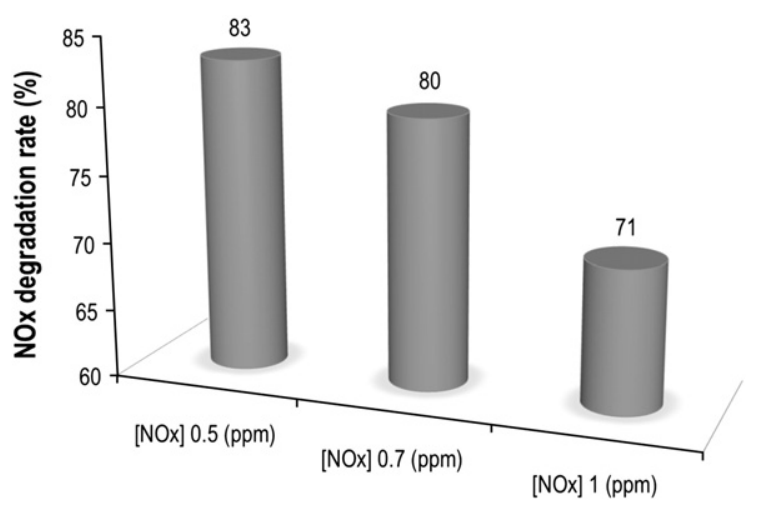

Fig. 18. Photocatalytic efficiency for $\mathrm{NO}_{\mathrm{x}}$ concentrations of $1,0.7$ and 5 ppmv. 


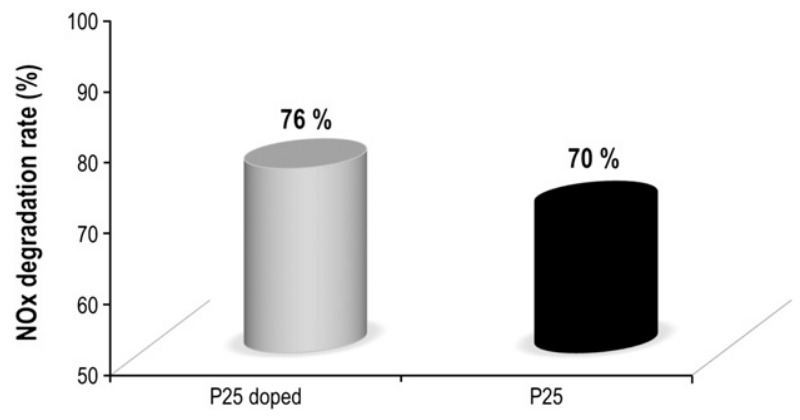

Fig. 19. Photocatalytic efficiency for non-doped and iron-doped titanium dioxide.

the reaction speed. For higher concentrations, the demand of active sites for the degradation process and larger quantities of intermediate products slows down the degradation rate.

- It was shown that doping titanium dioxide nanoparticles with iron (by a co-precipitation method) increases the photocatalytic efficiency.

An important relationship was established between the mortars microstructure (pore size and distribution) and the photocatalytic process. There is an optimal catalyst content for each mortar composition, which does not exceed, generally $2.5 \mathrm{wt} . \% \mathrm{TiO}_{2}$. The most favorable compositions combine a proper amount of catalyst (that does not cause deactivation), with a pore size distribution and total porosity that favors the pollutant access into the internal structure of the mortar.

It was established that it is possible to develop photocatalytic mortars, capable of reducing the pollutant concentration in indoor air, contributing to a more sustainable construction.

\section{Acknowledgments}

The authors acknowledge the Foundation for Science and Technology (FCT) for the financial support (PTDC/ECM/72104/2006).

\section{References}

[1] A. Fujishima, X.T. Zhang, D.A. Tryk, TiO2 photocatalysis and related surface phenomena, Surf. Sci. Rep. 63 (2008) 515-582.

[2] D. Reyes-Coronado, G. Rodríguez-Gattorno, M.E. Espinosa-Pesqueira, C. Cab, R.d. Coss, G. Oskam, Phase-pure $\mathrm{TiO}_{2}$ nanoparticles: anatase, brookite and rutile, Nanotechnology 19 (2008) 145605.

[3] A. Fujishima, X. Zhang, D.A. Tryk, Heterogeneous photocatalysis: from water photolysis to applications in environmental cleanup, Int. J. Hydrogen Energy 32 (2007) 2664-2672.

[4] M. Addamo, M. Bellardita, A. Di Paola, L. Palmisano, Preparation and photoactivity of nanostructured anatase, rutile and brookite TiO2 thin films, Chem. Commun. (2006) 4943-4945.

[5] S. Bakardjieva, V. Stengl, L. Szatmary, J. Subrt, J. Lukac, N. Murafa, D. Niznansky, K. Cizek, J. Jirkovsky, N. Petrova, Transformation of brookite-type TiO2 nanocrystals to rutile: correlation between microstructure and photoactivity, J. Mater. Chem. 16 (2006) 1709-1716.

[6] R.E. Stephens, B. Ke, D. Trivich, The efficiencies of some solids as catalysts for the photosynthesis of hydrogen peroxide, J. Phys. Chem. 59 (1955) 966-969.

[7] D.F. Ollis, E. Pelizzetti, N. Serpone, Photocatalyzed destruction of water contaminants, Environ. Sci. Technol. 25 (1991) 1522-1529.

[8] A.L. Linsebigler, G.Q. Lu, J.T. Yates, Photocatalysis on Tio2 surfaces - principles, mechanisms, and selected results, Chem. Rev. 95 (1995) 735-758.

[9] J. Chen, C.S. Poon, Photocatalytic construction and building materials: from fundamentals to applications, Build. Environ. 44 (2009) 1899-1906.

[10] J.H. Mo, Y.P. Zhang, Q.J. Xu, J.J. Lamson, R.Y. Zhao, Photocatalytic purification of volatile organic compounds in indoor air: a literature review, Atmos. Environ. 43 (2009) 2229-2246.

[11] J. Zhao, X.D. Yang, Photocatalytic oxidation for indoor air purification: a literature review, Build. Environ. 38 (2003) 645-654.

[12] D. Beydoun, R. Amal, G. Low, S. McEvoy, Role of nanoparticles in photocatalysis, J. Nanopart. Res. 1 (1999) 439-458.

[13] U.E., Directiva 2008/50/CE, relativa à qualidade do ar ambiente e a um ar mais limpo na Europa, in: Parlamento Europeu, Conselho da União Europeia, 2008.

[14] B. Berglund, B. Brunekreef, H. Knoppel, T. Undvaij, M. Maroni, L. Mblhave, P. Skov, in: Effects of Indoor Air Pollution on Human Health - Report nº10, Commission of the European Communities, Luxembourg, 1991.
[15] M. Jantunen, Effect of Outdoor Generated Pollutants on Indoor Air Quality and Health, in: FINVAC (Ed.), REHVA World Congress Clima 2007 Wellbeing Indoors, Helsinki, Finland, 2007.

[16] D.A. Vallero, Indoor Air Quality, in: Fundamentals of air pollution, Fourth edition, Academic Press, Burlington, 2007, pp. 679-695.

[17] J. Gunschera, J.R. Andersen, N. Schulz, T. Salthammer, Surface-catalysed reactions on pollutant-removing building products for indoor use, Chemosphere 75 (2009) 476-482.

[18] T. Salthammer, F. Fuhrmann, Photocatalytic surface reactions on indoor wall paint, Environ. Sci. Technol. 41 (2007) 6573-6578.

[19] M. Hunger, G. Husken, J. Brouwers, Photocatalysis applied to concrete products part 1: principles and test procedure, ZKG Int. 61 (2008) 77-85.

[20] G. Bolte, Innovative building materials - reduction of pollutants with TioCem (R) ZKG Int. 62 (2009) 63-70.

[21] F.L. Toma, G. Bertrand, D. Klein, C. Coddet, Photocatalytic removal of nitrogen oxides via titanium dioxide, Environ. Chem. Lett. 2 (2004) 117-121.

[22] J. Auvinen, L. Wirtanen, The influence of photocatalytic interior paints on indoor air quality, Atmos. Environ. 42 (2008) 4101-4112.

[23] M. Arandigoyen, B. Bicer-Simsir, J.I. Alvarez, D.A. Lange, Variation of microstructure with carbonation in lime and blended pastes, Appl. Surf. Sci. 252 (2006) 7562-7571.

[24] I. Karatasios, M.S. Katsiotis, V. Likodimos, A.I. Kontos, G. Papavassiliou, P. Falaras, V. Kilikoglou, Photo-induced carbonation of lime-TiO2 mortars, Appl. Catal. Environ. 95 (2010) 78-86.

[25] Y. Bai, G.E. Thompson, S. Martinez-Ramirez, Effects of NO2 on oxidation mechanisms of atmospheric pollutant SO2 over Baumberger sandstone, Build. Environ. 41 (2006) 486-491.

[26] V. Kukadia, J. Palmer, The effect of external atmospheric pollution on indoor air quality: a pilot study, Energy Build. 27 (1998) 223-230.

[27] J.S. Dalton, P.A. Janes, N.G. Jones, J.A. Nicholson, K.R. Hallam, G.C. Allen, Photocatalytic oxidation of $\mathrm{NO}_{\mathrm{x}}$ gases using TiO2: a surface spectroscopic approach, Environ. Pollut. 120 (2002) 415-422.

[28] A.P. Jones, Indoor air quality and health, Atmos. Environ. 33 (1999) 4535-4564.

[29] T. Maggos, J.G. Bartzis, P. Leva, D. Kotzias, Application of photocatalytic technology for $\mathrm{NO}_{\mathrm{x}}$ removal, Appl. Phys. A: Mater. Sci. Process. 89 (2007) 81-84.

[30] M.M. Ballari, M. Hunger, G.H. sken, H.J.H. Brouwers, Modelling and experimenta study of the $\mathrm{NO}_{\mathrm{x}}$ photocatalytic degradation employing concrete pavement with titanium dioxide, Catal. Today 151 (2010) 71-76.

[31] RCCTE, Regulamento das Características de Comportamento Térmico dos Edifícios (RCCTE), in: ERSE (Entidade reguladora dos serviços energéticos) (Ed.), Decreto-Lei no 80/2006, de 4 de Abril, Portugal, 2006.

[32] J.M. Herrmann, Heterogeneous photocatalysis: state of the art and present applications, Top. Catal. 34 (2005) 49-65.

[33] U.I. Gaya, A.H. Abdullah, Heterogeneous photocatalytic degradation of organic contaminants over titanium dioxide: a review of fundamentals, progress and problems, J. Photochem. Photobiol., C 9 (2008) 1-12.

[34] K. Derneestere, J. Dewulf, B. De Witte, A. Beeldens, H. Van Langenhove, Heterogeneous photocatalytic removal of toluene from air on building materials enriched with TiO2, Build. Environ. 43 (2008) 406-414.

[35] H.W. Shi, J.T. Zheng, Y. Hu, Y.C. Zhao, Influence of Fe3 + and Ho3 + co-doping on the photocatalytic activity of TiO2, Mater. Chem. Phys. 106 (2007) 247-249.

[36] P. Bouras, E. Stathatos, P. Lianos, Pure versus metal-ion-doped nanocrystalline titania for photocatalysis, Appl. Catal. Environ. 73 (2007) 51-59.

[37] M. Arandigoyen, J.L.P. Bernal, M.A.B. Lopez, J.I. Alvarez, Lime-pastes with different kneading water: pore structure and capillary porosity, Appl. Surf. Sci. 252 (2005) 1449-1459.

[38] J. Elsen, Microscopy of historic mortars - a review, Cem. Concr. Res. 36 (2006) 1416-1424.

[39] A. Nazari, S. Riahi, S. Riahi, S. Fatemeh, Shamekhi, A. Khademno, Improvement the mechanical properties of the cementitious composite by using TiO2 nanoparticles, J. Am. Sci. 4 (2010) 98-101.

[40] M.M. Hassan, H. Dylla, L.N. Mohammad, T. Rupnow, Evaluation of the durability of titanium dioxide photocatalyst coating for concrete pavement, Constr. Build Mater. 24 (2010) 1456-1461.

[41] O. Carp, C.L. Huisman, A. Reller, Photoinduced reactivity of titanium dioxide, Prog Solid State Chem. 32 (2004) 33-177.

[42] M.A. Fox, M.T. Dulay, Heterogeneous photocatalysis, Chem. Rev. 93 (1993) 341-357.

[43] S. Care, F.ß. Derkx, Determination of relevant parameters influencing gas permeability of mortars, Constr. Build. Mater. 25 (2011) 1248-1256.

[44] J. Chen, C.s. Poon, Photocatalytic cementitious materials: influence of the microstructure of cement paste on photocatalytic pollution degradation, Environ. Sci. Technol. 43 (2009) 8948-8952.

[45] A. Folli, I. Pochard, A. Nonat, U.H. Jakobsen, A.M. Shepherd, D.E. Macphee, Engineering photocatalytic cements: understanding $\mathrm{TiO} 2$ surface chemistry to control and modulate photocatalytic performances, J. Am. Ceram. Soc. 93 (2010) 3360-3369.

[46] E. Piera, J.A. Ayllón, X. Doménech, J. Peral, TiO2 deactivation during gas-phase photocatalytic oxidation of ethanol, Catal. Today 76 (2002) 259-270.

[47] L. Cao, Z. Gao, S.L. Suib, T.N. Obee, S.O. Hay, J.D. Freihaut, Photocatalytic oxidation of toluene on nanoscale TiO2 catalysts: studies of deactivation and regeneration, J. Catal. 196 (2000) 253-261.

[48] M. Hunger, G. Husken, J. Brouwers, Photocatalysis applied to concrete products Part 3: practical relevance and modeling of the degradation process, ZKG Int. 62 (2009) 63-70. 